\title{
Monticellite in Group-I kimberlites: Implications for evolution of parental melts and post-emplacement $\mathrm{CO}_{2}$ degassing
}

\author{
Adam Abersteiner ${ }^{1}$, Vadim S. Kamenetsky ${ }^{1}$, D. Graham Pearson ${ }^{2}$, Maya Kamenetsky ${ }^{1}$, \\ Karsten Goemann ${ }^{3}$, Kathy Ehrig ${ }^{4}$ \\ ${ }^{1}$ School of Physical Sciences, University of Tasmania, Australia, adam.abersteiner@utas.edu.au, \\ dima.kamenetsky@utas.edu.au,Maya.Kamenetsky@utas.edu.au \\ ${ }^{2}$ Department of Earth and Atmospheric Sciences, University of Alberta, Canada, gdpearso@ualberta.ca \\ ${ }^{3}$ Central Science Laboratory, University of Tasmania, Australia, Karsten.Goemann@utas.edu.au \\ ${ }^{4}$ BHP Billiton, Australia, Kathy.J.Ehrig@bhpbilliton.com
}

\section{Introduction}

Reconstructing the composition and evolution of kimberlite magmas is challenging because kimberlite rocks are no longer considered to be representative of their parental melts because of: i) entrainment and assimilation of mantle and crustal material, ii) volatile (e.g., $\mathrm{CO}_{2}, \mathrm{H}_{2} \mathrm{O}$ ) exsolution and degassing, and iii) kimberlite rocks are almost always altered by deuteric and/or hydrothermal/meteoric fluids.

In order to constrain the petrogenesis of Group-I (or archetypal) kimberlite melts, we examine monticellite which occurs as a magmatic and/or deuteric mineral in the groundmass of kimberlites, exclusively within minimally altered samples in highly variable amounts, rarely up to 80 vol. \% (Mitchell, 1986). In this contribution, we present a detailed petrographic and geochemical study of monticellite and monticellite-hosted inclusions from the Leslie (Slave Craton, Canada) and Pipe 1 (Karelian Craton, Finland) kimberlites to demonstrate the influence of monticellite crystallisation on kimberlite melt evolution and $\mathrm{CO}_{2}$ degassing.

\section{Petrography}

Samples LDC7 and FLP1 were examined by optical and scanning electron microscopy (SEM). Both samples are representative of Group-I (or archetypal) hypabyssal facies kimberlite and exhibit similar groundmass textures and mineralogy. Olivine is abundant ( 40 - 50 vol.\%), occurring as anhedral-torounded (up to $10 \mathrm{~mm}$ ) and euhedral phenocrystic grains $(<0.1->0.5 \mathrm{~mm})$ which exhibit limited alteration to serpentine and carbonate (i.e. calcite). The groundmass is characterised by (in order of relative abundance) monticellite, calcite, phlogopite/kinoshitalite, brucite, spinel (Cr-spinel, MUM, $\mathrm{Mg}$-magnetite, pleonaste), apatite, perovskite and $\mathrm{Fe}-\mathrm{Ni}-\mathrm{Cu}$-sulphides along with abundant alteration phases (i.e. brucite and interstitial serpentine and calcite).
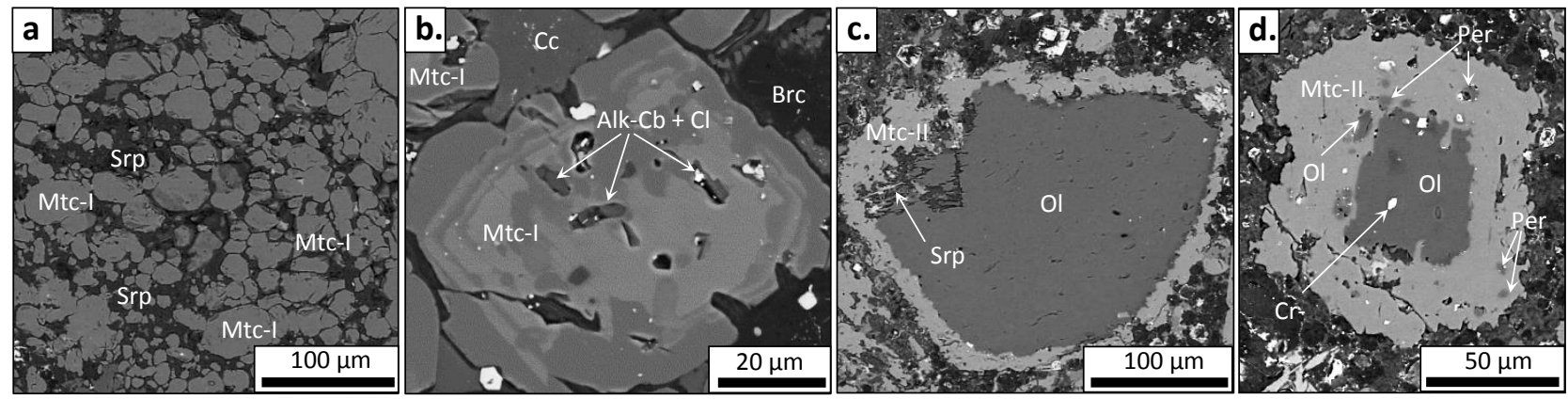

Figure 1. Back-scattered electron (BSE) SEM images of: $(a, b)$ Discrete monticellite-I (Mtc-I) grains in the groundmass of sample FLP1. (b) A concentrically zoned Mtc-I grain oscillating between lighter (more Fe-rich) and darker (less Ferich) areas. This grain also contains several multiphase inclusions consisting of alkali-carbonates (Alk-Cb) and chlorides $(\mathrm{Cl})$. (c, d) Olivine (Ol) partially replaced by monticellite-II (Mtc-II) in sample LDC7. Mtc-II commonly host abundant primary inclusions of periclase (Per). Srp: serpentine, Brc: brucite, Cc: calcite, Cr-Spl: Cr-spinel. 
Monticellite is a dominant groundmass mineral in samples LDC7 ( 25 vol.\%) and FLP1 ( 40 - 45 vol.\%) occuring as two distinct morphological types: i) Mtc-I: subhedral-to-euhedral microphenocrysts ranging from $10-150 \mu \mathrm{m}$ (Figs. 1a and b). Monticellite grains are generally uniformly distributed throughout the groundmass but also form densely packed clusters (Fig. 2a). The majority of monticellite grains exhibit compositional heterogeneity and zoning is usually patchy and diffuse, which is characterised by minor variations in Fe-content. ii) Mtc-II: forms pseudomorphs after olivine (Figs. 1c and d). Pseudomorphic monticellite sometimes completely replaces smaller olivine grains $(<50-100 \mu \mathrm{m})$. These completely replaced olivine grains are distinguished from discrete groundmass grains (i.e. Mtc-I) by the presence of small relic inclusions ( $<20 \mu \mathrm{m}$; Fig. 1d) of olivine and Cr-spinel, and the absence of zoning.

\section{Inclusions}

Monomineralic inclusions are typically round-to-euhedral in shape and range in size between $1-12$ $\mu \mathrm{m}$ and are comprised of (in order of decreasing abundance) periclase (Figs. 1d and 2), perovskite, phlogopite, Fe-Mg-Al-oxides (Mg-magnetite, pleonaste). To our knowledge, this is the first confirmation of periclase occurring in kimberlites.
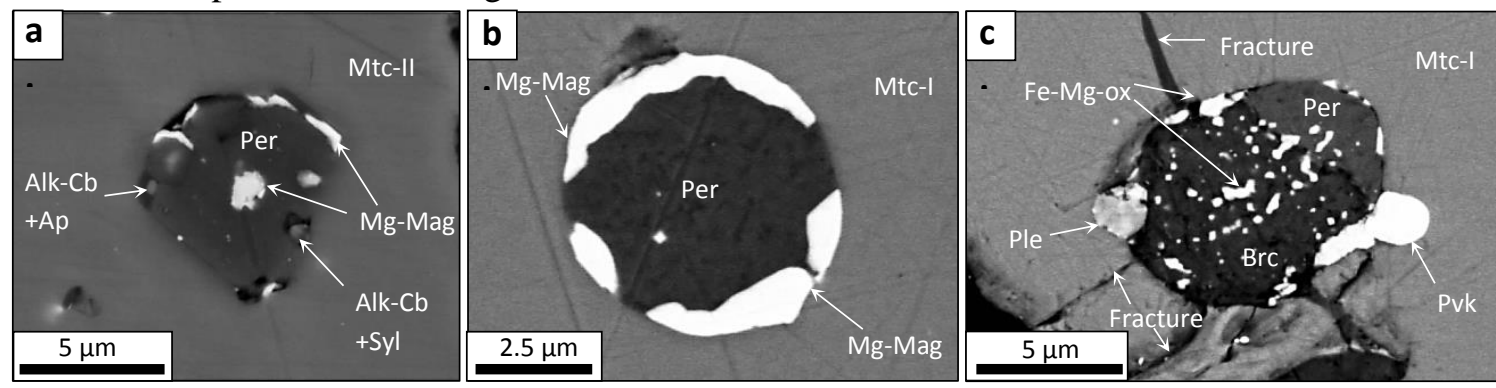

Figure 2. Back-scattered electron (BSE) SEM images of: (a) Periclase inclusions in Mtc-II (Mtc) replacing olivine in sample LDC7. These inclusions are commonly accompanied by a 'coating' along the inclusion peripheries of Mg-magnetite (Mg-mag) and occasionally other phases such as alkali-carbonates (Alk-Cb), apatite (Ap), and sylvite (Syl). (b, c) Periclase inclusions in groundmass Mtc-I grains in sample FLP1. (b) Similar to LDC7, this inclusion contains a 'coating' of Mg-magnetite along the inclusion peripheries; (c) An inclusion of periclase transected by multiple fractures, exposing it to post-entrapment alteration. Periclase and brucite (Brc) co-exist, where periclase has been partially altered to mixtures of brucite and disseminated Fe-Mg-oxides (Fe-Mg-Ox). This inclusion demonstrates the incomplete transformation of periclase to brucite. Ple: Pleonaste, Pvk: perovskite .

Multiphase (i.e. melt) inclusions are abundant in Mtc-II and to a lesser extent in Mtc-I and are sometimes associated with periclase inclusions (Fig. 2a). Multiphase inclusions in monticellite exhibit a variety of shapes, ranging from rounded-to-elongate and amoeboid and are $1-15 \mu \mathrm{m}$ in size (Fig. 3 ). These inclusions are extremely heterogeneous in composition and contain between two and six phases which are represented in order of abundance by calcite, alkali $(\mathrm{Na}, \mathrm{K}, \mathrm{Sr}, \mathrm{Ba}$ and some Fbearing $\pm \mathrm{V}$ ) carbonates, dolomite, periclase, Mg-Fe-Al-spinel, F-rich apatite, forsteritic olivine, sylvite/halite, perovskite, phlogopite and Ni-Fe-sulphides.
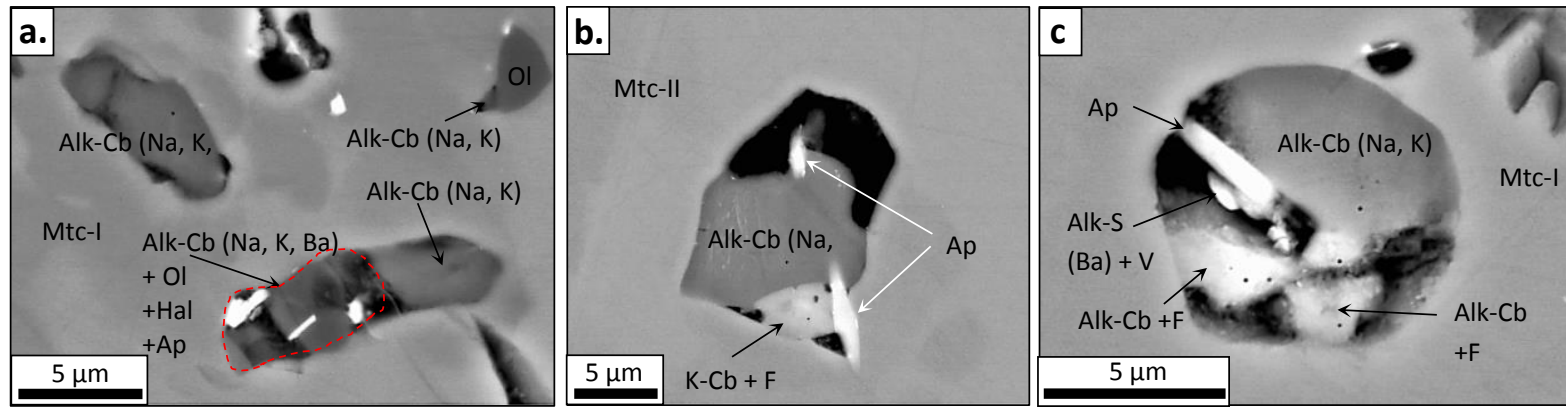

Figure 3. Back-scattered electron (BSE) SEM images of representative multiphase inclusions in monticellite (Mtc). These inclusions contain daughter crystals of alkali-carbonates (Alk-Cb) including fluorine $(\mathrm{F})$ bearing varieties, alkali-sulphur-bearing phase (Alk-S) that contain vanadium(V), halite (Hal), apatite (Ap) and olivine (Ol). 


\section{Discussion}

The preservation of Mtc-II suggests that monticellite crystallisation occurred in-situ after magma was emplacement and that the groundmass was not significantly disrupted by any physical processes such as mechanical rounding/abrasion, explosivity or brecciation. Previous studies of melt inclusions in olivine and magmatic minerals from various kimberlites worldwide (Golovin et al., 2007; Kamenetsky et al., 2012 Abersteiner et al., 2016), olivine and ilmenite in kimberlitic polymict breccias (Giuliani et al., 2012) and in mantle xenolith-hosted minerals (Soltys et al., 2016) report similar alkali-carbonate dominated, Si-Cl-P-bearing phase assemblages to the ones observed in our samples. We suggest that the melt inclusions in groundmass kimberlite minerals represent the entrapment of a variably differentiated kimberlite melt. Based on our analyses of melt inclusions, monticellite likely crystallised from a Ca-Mg and alkali ( $\mathrm{Na}, \mathrm{K}, \mathrm{Ba}, \mathrm{Sr}$ ) enriched, P-Cl-bearing, carbonate-silicate melt.

Petrographic and textural data indicates that olivine replacement by Mtc-II resulted from olivine reacting with the carbonate component of the kimberlite melt. A plausible scenario for this replacement of olivine could be attributed to a specific decarbonation reaction (i.e. release of $\mathrm{CO}_{2}$ ).

Reaction 1: $(\mathrm{Fe}, \mathrm{Mg})_{2} \mathrm{SiO}_{4}+\mathrm{CaCO}_{3} \rightleftharpoons \mathrm{Ca}(\mathrm{Fe}, \mathrm{Mg}) \mathrm{SiO}_{4}+(\mathrm{Fe}, \mathrm{Mg}) \mathrm{O}+\mathrm{CO}_{2}$ Olivine (forsterite) + Carbonate (melt) $\rightleftharpoons$ Monticellite + Periclase + Carbon Dioxide (vapour)

This reaction is supported by the preservation of abundant primary inclusions of periclase and to a lesser extent Fe-Mg-oxides in monticellite. Based on the preservation of primary periclase inclusions, we infer that periclase also existed in the groundmass, but was subsequently altered by post-magmatic processes to brucite and $\mathrm{Fe}-\mathrm{Mg}$-oxides.

Degassing of $\mathrm{CO}_{2}$ in the latter stages of kimberlite magma emplacement into the crust could be largely driven by the observed reaction between olivine and the carbonate melt. For this reaction to proceed, $\mathrm{CO}_{2}$ should be removed (i.e. degassed), which will cause further reaction and additional monticellite, periclase/Fe-Mg-oxides production and $\mathrm{CO}_{2}$ degassing in response to this chemical system change (Le Chatelier's principle). Our study demonstrates that these proposed decarbonation reactions may be a commonly overlooked process in the crystallisation of monticellite and exsolution of $\mathrm{CO}_{2}$, which may in turn contribute to the explosive eruption and brecciation processes that occur during kimberlite magma emplacement and pipe formation.

\section{References}

Abersteiner A, Giuliani A, Kamenetsky VS, Phillips D (2016) Petrographic and melt-inclusion constraints on the petrogenesis of a magmaclast from the Venetia kimberlite cluster, South Africa. Chem Geol: http://dx.doi.org/10.1016/j.chemgeo.2016.08.029.

Golovin AV, Sharygin VV, Pokhilenko NP (2007) Melt inclusions in olivine phenocrysts in unaltered kimberlites from the Udachnaya-East pipe, Yakutia: Some aspects of kimberlite magma evolution during late crystallization stages. Petrology 15:168-183.

Giuliani A, Kamenetsky VS, Phillips D, Kendrick MA, Wyatt BA, Goemann K (2012) Nature of alkali-carbonate fluids in the sub-continental lithospheric mantle. Geology 40:967-970.

Kamenetsky, VS, Kamenetsky, MB, Golovin, AV., Sharygin, VV, Maas, R (2012) Ultrafresh salty kimberlite of the Udachnaya-East pipe (Yakutia, Russia): A petrological oddity or fortuitous discovery? Lithos 152, 173-186.

Mitchell RH, 1986. Kimberlites: Mineralogy, Geochemistry and Petrology. Plenum Publishing Company, New York.

Soltys A, Giuliani A, Phillips D, Kamenetsky VS, Maas R, Woodhead J, Rodemann T (2016) In-situ assimilation of mantle minerals by kimberlitic magmas - Direct evidence from a garnet wehrlite xenolith entrained in the Bultfontein kimberlite (Kimberley, South Africa). Lithos 256-257:182196. 